\title{
ATTITUDES OF DIABETIC PATIENTS TOWARD THEIR DISEASE
}

\section{POSTAWY PACJENTÓW CHORYCH NA CUKRZYCE WOBEC ICH CHOROBY}

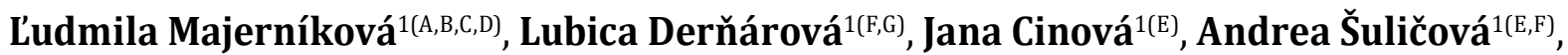 Zuzana Novotná ${ }^{1(\mathrm{D}, \mathrm{E}, \mathrm{F})}$, Tatiana Šantova ${ }^{1(\mathrm{E}, \mathrm{F})}$}

\author{
${ }^{1}$ University of Prešov, Slovakia
}

\author{
Authors' contribution \\ Wkład autorów: \\ A. Study design/planning \\ zaplanowanie badań \\ B. Data collection/entry \\ zebranie danych \\ C. Data analysis/statistics \\ dane - analiza i statystyki \\ D. Data interpretation \\ interpretacja danych \\ E. Preparation of manuscript \\ przygotowanie artykułu \\ F. Literature analysis/search \\ wyszukiwanie i analiza literatury \\ G. Funds collection \\ zebranie funduszy
}

\section{Tables: 6}

Figures: 0

References: 25

Submitted: 2019 March 5

Accepted: 2019 Jun 6

\section{Summary}

Background. Education of diabetic patients is integral to effective treatment.

Material and methods. In the presented work, we studied Eastern Slovakian patients with diabetes type 2 with or without insulin treatment. We focused on their diabetic self-care and compared their attitudes, education on their disease, and treatment provided by professionals. There were 411 patients in the insulin-treated group. We used the standardized Diabetes Care Profile questionnaire (DCP).

Results. The groups had very different attitudes toward diabetic self-care. Patients with provided professional self-care education scored higher in all areas of diabetic care. Appropriate education influenced knowledge and consequently the management and attitudes of diabetic patients toward their disease. Educated patients scored higher in the categories 'Self-care ability', 'Importance of care', 'Self-care adherence', 'Diet adherence', 'Medical barriers', 'Exercise barriers', 'Monitoring barriers' and 'Understanding practice' $(p<0.01)$. Patients who had not received diabetes education presented higher scores in emotional areas, i.e., negative and positive attitudes toward diabetes mellitus $(\mathrm{p}<0.01)$.

Conclusions. We concluded that it is beneficial for a structured educational process to be integrated in diabetes treatment.

Keywords: education, diabetes mellitus, nursing, attitudes

\section{Streszczenie}

Wprowadzenie. Edukacja pacjentów chorych na cukrzycę stanowi integralną część ich skutecznego leczenia.

Materiał i metody. W prezentowanym badaniu porównano postawy w zakresie samodzielnej profilaktyki cukrzycy w dwóch grupach pacjentów cierpiących na cukrzyce typu 2, która wymaga insulinoterapii, w odniesieniu do szkoleń edukacyjnych dotyczących ich choroby oraz leczenia prowadzonego przez specjalistów. Badaną grupę stanowiło 411 pacjentów cierpiących na cukrzycę typu 2 leczoną za pomocą insuliny, którzy pochodza ze wschodniej części Słowacji. Zastosowano standardowy kwestionariusz DCP (ang. Diabetes Care Profile), wykorzystywany do oceny czynników społecznych i psychologicznych wśród cukrzyków.

Wyniki. Postawy dwóch porównywanych grup pacjentów wobec cukrzycy różniły się istotnie w zakresie samodzielnej profilaktyki. Pacjenci z zapewnionym profesjonalnym szkoleniem dotyczącym samodzielniej profilaktyki uzyskiwali wyższe oceny we wszystkich obszarach związanych z monitorowaniem i leczeniem cukrzycy. Prawidłowy proces edukacyjny mawpływ na poziom wiedzy, a tym samym na działania podejmowane przez pacjentów i ich postawy wobec choroby. Pacjenci, którzy otrzymali odpowiednie przeszkolenie, lepiej kontrolowali sfery takie jak „Umiejętności dot. samodzielnej profilaktyki”, ,Znaczenie samodzielnej profilaktyki”, „Przestrzeganie zasad samodzielnej profilaktyki”, „Przestrzeganie diety”, „Ograniczenia "natury medycznej”, „Ograniczenia w wykonywaniu ćwiczeń”, „Ograniczenia w monitorowaniu” oraz „Rozumienie procedur” ( $p<0,01)$. Z kolei pacjenci nieposiadający odpowiedniej wiedzy prezentowali lepsze wyniki w obszarach związanych ze sferą emocjonalną - negatywnym i pozytywnym nastawieniu do cukrzycy $(\mathrm{p}<0,01)$.

Wnioski. W kontekście uzyskanych wyników, zintegrowanie ustrukturyzowanego procesu edukacyjnego z leczeniem osób chorujących na cukrzycę wydaje się konieczne.

Słowa kluczowe: edukacja, cukrzyca, opieka pielęgniarska, postawy 


\section{Introduction}

Diabetes is a chronic disease that requires patients make a multitude of daily self-management decisions and perform complex care activities. Diabetes self-management education and support (DSME/S) provides the foundation for diabetic patients to navigate these decisions and activities and has been shown to improve health outcomes [1, 2, 3]. Diabetes self-management education (DSME) is the process of facilitating the knowledge, skills, and abilities necessary for diabetes self-care. Diabetes self-management support (DSMS) refers to the support needed to implement and sustain coping skills and self-management behaviors. Although many different members of the healthcare team and community contribute to this process, it is important that health care providers and their practice settings have the resources and a systematic referral process to ensure that patients consistently receive both DSME and DSMS. The initial DSME is typically provided by a health professional, whereas ongoing support can be provided by personnel within a practice and by a variety of community-based resources. DSME/S programs are designed to address the patient's health beliefs, cultural needs, current knowledge, physical limitations, emotional concerns, family support, financial status, medical history, health literacy, numeracy, and other factors to help meet the challenges of self-management [1, 2, 4]. The statement of rights and responsibilities of diabetic patients formulated in the Saint Vincent declaration establishes, among other things, the right to continuous education for all diabetic patients and their families. Effective education therefore achieves the objectives of the aforementioned declaration and prevents acute and chronic complications. In addition, it should improve the quality of life of diabetic patients and their families. For this reason, the presented work focuses on the comparison of insulin-treated diabetic patients with and without health professional-provided education. The objective of this work was to monitor, analyze and evaluate differences in attitudes, realization of diabetic self-care and self-monitoring by patients with type 2 diabetes mellitus with insulin treatment in relation to the provided education $[5,6]$.

\section{Material and methods}

The aim of this study was to investigate the effects of complex education on the attitudes type 2 diabetics have toward their diabetes care management.

500 questionnaires were distributed to patients in Eastern Slovakia (location Košice, Prešov, Sabinov, Vranov nad Toplou) with type 2 diabetes mellitus (DM2T) treated with insulin. 411 questionnaires were returned (response rate 82\%). We used the questionnaire "Diabetes Care Profile (DCP)" [7]. The DCP was developed as an instrument to assess social and psychological factors related to diabetes and its treatment. To compare the selected indicators, the sample was divided based on the answers provided for the sections of the DCP questionnaire "Education/Provided Advice" and "Diet". Two groups of patients were selected in relation to the education realized by health professionals (patients with acquired education EP and without education NP). The study was conducted on 411 patients with insulin-treated type 2 diabetes mellitus (DM2T). The inclusion criteria were the adult age of patients, DM2T disease and insulin treatment. The average age of respondents was 62.9 years. The major age groups were late adulthood and presenium.

\section{Data analysis}

For the purpose of the presented study, a standardized questionnaire for acquisition of needed information, "Diabetes Care Profile", was used. SPSS 15.0 was used for statistical analysis of the obtained data. T- and F-tests were used to compare the studied groups to determine statistical differences ( $p$ - statistic value, M - mean, SD - standard deviation).

We focused on the education provided by health professionals (doctor, nurse, nutrition assistant) in the fields of podiatry, physical exercise, diet and the necessity of adherence to the diet, meal planning, measurement of food weight and the use of special diabetic menus. In terms of education in the area of podiatry, 100\% of respondents from the first EP group answered positively to this item, while $98.5 \%$ of respondents from the second NP group gave a negative response. $96 \%$ of EP respondents received consultations about physical exercise, and about $91 \%$ of NP respondents answered negatively. The EP were fully educated about issues of diabetic diet, its importance, dietary adherence and measurement of food weight; the NP were not (negative responses). In terms of formal education through repeated meetings with an expert in the field of diabetic education, 75\% of EP answered positively and $96 \%$ of NP negatively. Based on these findings, the whole sample of respondents was divided into two groups. The educated patients (EP) comprised 232 patients, and the 'not educated patients' (NP) comprised 179 patients (Table 1 ). 
Table 1. Characteristic of respondents

\begin{tabular}{|c|c|c|c|c|}
\hline \multirow{2}{*}{ Characteristic } & \multicolumn{2}{|c|}{ EDUCATED PATIENTS (EP) } & \multicolumn{2}{|c|}{ NOT EDUCATED PATIENTS (NP) } \\
\hline & n (232) & $\%$ & n (179) & $\%$ \\
\hline $\begin{array}{l}\text { Gender } \\
\text { Male } \\
\text { Female }\end{array}$ & $\begin{array}{c}94 \\
128\end{array}$ & $\begin{array}{l}40 \% \\
60 \%\end{array}$ & $\begin{array}{c}68 \\
111\end{array}$ & $\begin{array}{l}38 \% \\
62 \%\end{array}$ \\
\hline $\begin{array}{l}\text { Education } \\
\text { Primary school graduate or less } \\
\text { Secondary school graduate or more }\end{array}$ & $\begin{array}{c}69 \\
162\end{array}$ & $\begin{array}{l}30 \% \\
70 \%\end{array}$ & $\begin{array}{c}52 \\
127\end{array}$ & $\begin{array}{l}29 \% \\
71 \%\end{array}$ \\
\hline Age $(M \pm S D)$ & $62.8 \pm 11.26$ & & $63.1 \pm 11.12$ & \\
\hline $\begin{array}{l}\text { Duration of diabetes mellitus } \\
(M \pm S D)\end{array}$ & $11.2 \pm 7.17$ & & $10.8 \pm 6.72$ & \\
\hline $\mathrm{HbA} C(\mathrm{M} \pm \mathrm{SD})$ & $8.84 \pm 1.54$ & & $8.85 \pm 2.0$ & $\mathrm{p}=0.72$ \\
\hline $\mathrm{BMI}(\mathrm{M} \pm \mathrm{SD})$ & $29.93 \pm 5.30$ & & $30.42 \pm 4.59$ & $\mathrm{p}=0.52$ \\
\hline
\end{tabular}

$\mathrm{N}$ - number, $\mathrm{M}$ - mean, SD - standard deviation

Ethics

Research took place in accordance with the Helsinki Declaration and a local ethical committee approved the study. All participants signed an informed consent document.

\section{Results}

The majority of respondents were female. The EP group was $60 \%$ female and $40 \%$ male. The NP group was $62 \%$ female and 38\% men (Table 1). The prevailing age in the EP group was 51-60 years (38.8\%) while for the NP group, it was 61-70 years (48\%). The mean age was 62.2 years for the EP respondents (SD 11.26) and 62.4 years (SD 11.12) for NP.

The total duration of diabetes for the whole study group of respondents was 11.12 years (SD 7.12). The EP group's mean duration was 11.2 years (SD 7.17) and the NP group's mean duration was 10.8 (SD 6.72). For both groups' mean duration, the largest category was 10-14 years. Only 13\% of EP and 9\% of NP had a BMI in the normal range. T-tests did not show any significant differences in BMI in the studied groups $(p=0.52)$. Glycated hemoglobin levels (HbA1C) were $8.84 \pm 1.54$ for EP and $8.85 \pm 2.0$ for NP. Differences were not statistically significant $(\mathrm{p}=0.72)$ (Table 1$)$.

Table 2 presents a summary of the results for each DCP scale. We analyzed the effects of education. The 16 subscales of the DCP were compared for the educated and non-educated groups of patients (Table 2).

Table 2. Summary DCP scale

\begin{tabular}{|c|c|c|c|c|c|}
\hline \multirow{2}{*}{ Scale } & \multicolumn{2}{|c|}{ EP } & \multicolumn{2}{|c|}{ NP } & \multirow{2}{*}{$\mathbf{p}$} \\
\hline & $\mathbf{M}$ & SD & M & SD & \\
\hline Control problems & 3.36 & 0.89 & 2.59 & 0.91 & $0.000^{* * *}$ \\
\hline Social and personal factors & 2.94 & 1.17 & 2.46 & 1.1 & $0.000 * * *$ \\
\hline Positive attitude & 2.35 & 0.92 & 3.41 & 1.09 & $0.000 * * *$ \\
\hline Negative attitude & 1.78 & 1.17 & 2.78 & 0.88 & $0.000 * * *$ \\
\hline Self-care ability & 3.68 & 0.95 & 2.19 & 0.97 & $0.000^{* * *}$ \\
\hline Importance of care & 3.03 & 1.49 & 2.04 & 0.93 & $0.000^{* * *}$ \\
\hline Self-care adherence & 3.51 & 0.92 & 2.09 & 0.94 & $0.000 * * *$ \\
\hline Diet adherence & 3.47 & 1.11 & 2.55 & 0.83 & $0.000 * * *$ \\
\hline Medical barriers & 2.86 & 1.34 & 2.27 & 1.16 & $0.000^{* * *}$ \\
\hline Exercise barriers & 2.8 & 1.28 & 2.14 & 0.89 & $0.000^{* * *}$ \\
\hline Monitoring barriers & 3.47 & 1.18 & 2.16 & 1 & $0.000 * * *$ \\
\hline Understanding management practice & 3.24 & 1.24 & 2.84 & 1.06 & $0.000 * * *$ \\
\hline Long-term care benefits & 3.49 & 1.05 & 3 & 1.13 & $0.000^{* * *}$ \\
\hline Support needs & 3.78 & 0.91 & 3.48 & 1.04 & $0.011^{*}$ \\
\hline Support & 3.66 & 0.91 & 3.31 & 1.24 & $0.007^{*}$ \\
\hline Support attitudes & 3.25 & 1.19 & 2.12 & 0.95 & $0.000 * * *$ \\
\hline
\end{tabular}

${ }^{*} \mathrm{p}<0.05{ }^{* *} \mathrm{p}<0.01 ;{ }^{* *} \mathrm{p}<0.001, \mathrm{M}-$ mean, SD - standard deviation, EP - educated patient, NP - not educated patient 
Educated patients reported higher 'Self-care ability', 'Importance of care', 'Self-care adherence', 'Diet adherence', 'Medical barriers', 'Exercise barriers', 'Monitoring barriers' and 'Understanding practice' ( $p<0.01)$. Not educated patients presented higher scores in emotional areas - negative and positive attitude to diabetes mellitus $(\mathrm{p}<0.01)$.

Understanding about diabetic care in the DCP focused on the assessment of lifestyle knowledge. The patients were evaluated on 12 items of diabetic self-treatment from 1-5 on the Likert scale ( $1=$ poor, $5=$ excellent $)$. The results confirmed statistically significant differences in lifestyle knowledge of patients with diabetes (Table 3).

Table 3. Evaluation of knowledge on lifestyle

\begin{tabular}{|l|c|c|c|c|c|}
\hline \multirow{2}{*}{\multicolumn{1}{|c|}{ Evaluated knowledge }} & \multicolumn{2}{c|}{ EP } & \multicolumn{2}{c|}{ NP } & P \\
\cline { 2 - 5 } & M & SD & M & SD & 0.91 \\
\hline a) overall diabetes care & 3.36 & 0.89 & 2.59 & $0.000^{* * *}$ \\
\hline b) coping with stress & 2.94 & 1.17 & 2.46 & 1.1 & $0.000^{* * *}$ \\
\hline c) diabetic diet & 3.41 & 0.92 & 2.35 & 1.09 & $0.000^{* * *}$ \\
\hline d) role of physical exercise in diabetes care & 2.78 & 1.17 & 1.78 & 0.88 & $0.000^{* * *}$ \\
\hline e) medications you are taking & 3.68 & 0.95 & 2.19 & 0.97 & $0.000^{* * *}$ \\
\hline $\begin{array}{l}\text { f) how to use results of self-monitoring } \\
\text { of blood glucose }\end{array}$ & 3.03 & 1.49 & 2.04 & 0.93 & $0.000^{* * *}$ \\
\hline $\begin{array}{l}\text { g) effects of diet, physical exercises and } \\
\text { medicines on amount of glucose in blood }\end{array}$ & 3.51 & 0.92 & 2.09 & 0.94 & $0.000^{* * *}$ \\
\hline $\begin{array}{l}\text { h) prevention and treatment of high blood } \\
\text { sugar }\end{array}$ & 3.47 & 1.11 & 2.55 & 0.83 & $0.000^{* * *}$ \\
\hline $\begin{array}{l}\text { i) prevention and treatment of low blood } \\
\text { sugar }\end{array}$ & 2.86 & 1.34 & 2.27 & 1.16 & $0.000^{* * *}$ \\
\hline $\begin{array}{l}\text { j) prevention of long-term complications } \\
\text { of diabetes (chronic complications) }\end{array}$ & 2.8 & 1.28 & 2.14 & 0.89 & $0.000^{* * *}$ \\
\hline k) foot care & 3.47 & 1.18 & 2.16 & 1 & $0.000^{* * *}$ \\
\hline l) benefits of self-monitoring blood glucose & 3.25 & 1.19 & 2.12 & 0.95 & $0.000^{* * *}$ \\
\hline
\end{tabular}

${ }^{*} \mathrm{p}<0.05{ }^{* *} \mathrm{p}<0.01 ;{ }^{* * *} \mathrm{p}<0.001, \mathrm{M}-$ mean, SD - standard deviation, EP - educated patient, NP - not educated patient

The importance of long-term diabetes care and effects of long-term care on possible health problems related to the development of chronic diabetic complications were studied. In this area, significantly different attitudes toward these problems were observed, where the studied group of the EP demonstrated a more positive attitude toward prevention of possible complications. The highest level of significance was recorded in the prevention of foot and renal problems $(\mathrm{p}<0.001)$. Statistically significant differences were also found for monitoring eye problems $(\mathrm{p}<0.01)$, risk of developing atherosclerosis $(\mathrm{p}<0.05)$ and heart disease $(\mathrm{p}<0.05)$. The results of the EP and NP groups in relation to their attitudes toward the importance of long-term treatment and control of DM are presented in Table 4.

Table 4. Attitudes toward importance of long-term treatment and control of diabetes

\begin{tabular}{|l|c|c|c|c|c|}
\hline \multirow{2}{*}{\multicolumn{1}{c|}{ Effects of long-term self-care }} & \multicolumn{2}{c|}{ EP } & \multicolumn{2}{c|}{ NP } & \multirow{2}{*}{ p } \\
\cline { 2 - 6 } & M & SD & M & SD & $0.004^{* *}$ \\
\hline a) eye problems & 3.85 & 0.99 & 3.47 & 1.18 & $0.000^{* * *}$ \\
\hline b) renal problems & 3.76 & 1.08 & 3.29 & 1.09 & 0.00 \\
\hline c) foot problems & 3.94 & 0.93 & 3.39 & 1.14 & $0.000^{* * *}$ \\
\hline d) atherosclerosis & 3.63 & 0.97 & 3.34 & 1.1 & $0.020^{*}$ \\
\hline e) heart diseases & 3.68 & 0.88 & 3.43 & 1.11 & $0.047^{*}$ \\
\hline
\end{tabular}

${ }^{*} \mathrm{p}<0.05$; $^{* *} \mathrm{p}<0.01 ;{ }^{* * *} \mathrm{p}<0.001, \mathrm{M}-$ mean, SD - standard deviation, EP - educated patient, NP - not educated patient

Using descriptive statistics, we found that $48 \%$ of the EP and $43 \%$ of the NP have well-controlled blood sugar. Self-monitoring of glycosuria and acetonuria was performed by only $16 \%$ of the EP and $17 \%$ of the NP.

For self-monitoring, the most frequent obstacles to realization are listed in Table 5 and were statistically significant $(p<0.05)$. Another obstacle to self-monitoring at the level of significance $(p<0.05)$ was that the respondents do not like performing self-monitoring, with positive scores for the EP $-1.61 \pm 1.01$, the NP $-2.1 \pm 1.35$. Another self-monitoring barrier was a lack of test materials, with the EP having greater access (Table 5) (EP 1.76 
\pm 1.12 , NP $2.32 \pm 1.29 ; \mathrm{p}<0.01)$. The NP group $(2.49 \pm 1.17)$ found self-monitoring more expensive than the EP group $(1.91 \pm 1.16)(p<0.01)$. Further significant differences in the terms of obstacles to self-monitoring were recorded in the following areas: assessment of blood sugar levels too complicated $(\mathrm{p}<0.05)$, inability to do it on their own $(p<0.01)$, glycemic levels do not change very often $(p<0.01)$ and discomfort when repeatedly pricking their fingers $(\mathrm{p}<0.05)$. All of these obstacles to self-monitoring were statistically significant (Table 5).

Table 5. Obstacles to self-monitoring

\begin{tabular}{|c|c|c|c|c|c|}
\hline \multirow{2}{*}{$\begin{array}{l}\text { You did not measure the glucose in your } \\
\text { blood as recommended because: }\end{array}$} & \multicolumn{2}{|c|}{ EP } & \multicolumn{2}{|c|}{ NP } & \multirow{2}{*}{$\mathbf{p}$} \\
\hline & $\mathbf{M}$ & SD & $\mathbf{M}$ & SD & \\
\hline a) you forgot it & 2.12 & 1.2 & 1.9 & 1.2 & 0.325 \\
\hline b) you do not believe it is useful & 1.49 & 1.07 & 2 & 1.44 & $0.019 *$ \\
\hline $\begin{array}{l}\text { c) you did not have enough time or a suitable } \\
\text { place for it }\end{array}$ & 1.58 & 0.96 & 1.83 & 1.12 & 0.163 \\
\hline d) you do not like it & 1.61 & 1.01 & 2.1 & 1.35 & $0.016^{*}$ \\
\hline e) you ran out of test materials & 1.76 & 1.12 & 2.32 & 1.29 & $0.006^{* *}$ \\
\hline f) it is too expensive & 1.91 & 1.16 & 2.49 & 1.17 & $0.003^{* *}$ \\
\hline g) it is complicated & 1.38 & 0.82 & 1.71 & 1.11 & $0.048^{*}$ \\
\hline h) it is difficult to read the test results & 1.45 & 0.9 & 1.67 & 1.11 & 0.200 \\
\hline i) I cannot do it on my own & 1.37 & 0.86 & 1.95 & 1.36 & $0.003^{* *}$ \\
\hline $\begin{array}{l}\text { j) your blood sugar level does not change } \\
\text { very often }\end{array}$ & 2.06 & 1.34 & 2.8 & 1.41 & $0.0015^{* *}$ \\
\hline k) repeated finger pricks are painful & 2.22 & 1.27 & 2.74 & 1.35 & $0.019 *$ \\
\hline
\end{tabular}

${ }^{*} \mathrm{p}<0.05$; $^{* *} \mathrm{p}<0.01$; $^{* *} \mathrm{p}<0.001, \mathrm{M}-$ mean, SD - standard deviation, EP - educated patient, NP - not educated patient

For monitoring of obstacles to self-monitoring and self-care we studied how the patients assess their practical skills using the Likert scale of assessment (1 - weak, 5 - perfect). We recorded significant differences in the responses, where the EP group assessed their skills better. Significant differences were monitored in skills related to adherence to diet and monitoring blood sugar levels $(\mathrm{p}<0.05)$, control and maintenance of a healthy body weight $(\mathrm{p}<0.01)$, prevention of diabetes complications $(\mathrm{p}<0.05)$, taking care of feet $(\mathrm{p}<0.05)$, and taking care of eyes $(\mathrm{p}<0.05)$ (Table 6$)$.

Table 6. Skills related to self-monitoring and self-care of patients with diabetes

\begin{tabular}{|c|c|c|c|c|c|}
\hline \multirow{2}{*}{ Evaluation of skills } & \multicolumn{2}{|c|}{ EP } & \multicolumn{2}{|c|}{ NP } & \multirow{2}{*}{$\mathbf{P}$} \\
\hline & $\mathbf{M}$ & SD & M & SD & \\
\hline a) follow diet and test blood sugar & 3.27 & 1.06 & 2.92 & 1.22 & $0.045^{*}$ \\
\hline b) control and maintain healthy body weight & 3.27 & 0.93 & 2.80 & 1.28 & $0.002^{* *}$ \\
\hline c) get physical activity & 2.62 & 1.37 & 2.28 & 1.07 & 0.066 \\
\hline d) take insulin/medicines & 3.64 & 0.95 & 3.41 & 1.31 & 0.175 \\
\hline e) monitor blood sugar levels & 3.40 & 1.01 & 3.20 & 1.43 & 0.269 \\
\hline f) take care of feet & 3.19 & 1.02 & 2.77 & 1.14 & $0.010^{*}$ \\
\hline g) prevent complications of diabetes & 3.04 & 1.16 & 2.67 & 1.26 & $0.041^{*}$ \\
\hline h) take care of eyes & 3.09 & 0.96 & 2.74 & 1.08 & $0.022^{*}$ \\
\hline i) consume alcohol with diabetes & 3.21 & 1.34 & 2.91 & 1.25 & 0.124 \\
\hline
\end{tabular}
${ }^{*} \mathrm{p}<0.05 ;^{* *} \mathrm{p}<0.01 ;^{* * *} \mathrm{p}<0.001$

\section{Discussion}

Diabetes is rapidly becoming the scourge of the modern world. The increasing number of diabetics is linked to the pandemic of obesity and metabolic syndrome, the aging population, as well as stricter diagnostic criteria. In 2016, there were 370,000 registered patients with diabetes in Slovakia. The number of diabetic ambulances and healthcare staff in Slovakia has clearly not developed in conformity with the high growth of diabetic patients and patients at risk of developing diabetes [8]. In addition, the study revealed that nurses mentioned the lack of time as the biggest problem in education of patients with DM. Other problems in the education of patients defined by nurses included the lack of equipment and educational standards.

Diabetes patients should consider diabetes education as an opportunity to solve emotional, social, behavioral, spiritual and psychological, as well as physical problems associated with this disease. The educational 
process should help patients further develop their knowledge, skills, attitudes and self-confidence necessary for effective health decisions. Strengthening attitudes toward self-care among patients with diabetes is a subject of psychosociological studies that help individuals develop their skills and introspection by determining objectives, solving problems, managing stress, and looking for social assistance and motivation. Patients should be able to make informed decisions about their diabetic care $[9,10]$. Collaborative decision-making represents a conceptual shift in the relationship between patients and educators. Patients are no longer only customers using medical services; they become active partners in providing medical care $[5,11,12]$. In the international literature, we often read about the education concentrating on the self-management of the disease, i.e., Diabetes Self-Management Education (DSME). The issue of education of diabetes patients in the area of self-management of their disease is considered one of the most important priority areas, and is related to self-care. Every diabetic patient should obtain knowledge and skills necessary for the diabetic self-care through education and reeducation. The objective of educational meetings is to regularly assess the overall level of self-care by diabetes patients $[13,14,15]$. Our study's questionnaire did not exactly follow the difference between ESMS and ESME.

Diabetic self-care represents the ability of a diabetic patient to manage overall self-care and everyday activities related to diabetes including blood glucose monitoring, taking medications, balanced eating and physical activity [16]. In terms of diabetes self-care, the healthcare provider acts as an educator with influence on their patient's health. As this kind of medical care is unique, effective communication between patients and health care providers is vital $[15,17]$. Overall health professional - patient education relates to many variables, including the patients' satisfaction and diabetic care abilities $[18,19,20]$.

In our research, we monitored the respondents' diabetic self-care ability, understanding of its importance and compliance. The objective was to find out if the attitudes of the groups differed significantly. The studied groups differed significantly in all four studied items. Fitzgerald et al. [21] studied the influence of treatment modality and ethnicity on the attitudes of diabetic patients toward their disease. The respondents were divided into 4 groups (2 ethnic groups and 2 treatment groups). 6 out of 16 sections of the DCP (control, social and personal factors, positive and negative attitudes, ability of diabetic self-care and barriers to physical exercises) were significantly affected by treatment modality. The four groups had statistically significant differences in their attitudes toward the disease. Gurková et al. [22] argued that patients who acquired an intensive educational program practiced all important self-care activities to a greater extent than patients who acquired the education from outpatient care. The structured educational program was provided for patients with types 1 and 2 diabetes with intensified insulin therapy. The objective was to improve diabetic metabolic compensation and re-education. The educational program for patients with DM1T was realized in the form of 10-day intensive education courses with a maximum of 10 participants per group. The clinical efficiency of the program in terms of changes in behavior and satisfaction with the treatment was not continuously assessed. Statistical comparison using the chi-square test revealed significant differences in the self-management of DM (based on saccharide units, $\mathrm{p}<0.05$ ). There were no statistically significant differences in the areas of regular self-monitoring, changes in insulin dosage in relation to specific situations and recordkeeping of hypoglycemia [22]. We obtained similar results in this paper, where in the area of diet adherence, adherence to meal plans and measuring/weighting of food were statistically significant between the groups $(\mathrm{p}<0.05)$.

Patient education is an ongoing process, which should be aimed at helping patients better manage glycemic control, overcome behavioral and psychological barriers, improve self-management skills, and become empowered to make informed choices $[9,12,18,23,24]$.

Based on our results, we recommend:

1. In each care provision, assessment of the patient with DM is important: A. Assessing the level of knowledge and skills; B. Values, attitudes, norms, and beliefs; C. Aids, means, external conditions (necessary for achieving educational goals); D. Will, Willingness, Motivation to Learn (Compliance / Adherence); E. The occurrence of negative emotions (fear, anxiety, anger, helplessness, guilt, suffering, and depression); F. Age, gender, level of education, and social status; G. Duration of DM, repeated hospitalization, and membership in self-help diabetic club.

2. The results of our study emphasize the importance of reinforcement of diabetes education including management of diet through stakeholders (healthcare providers, health facilities) to encourage them to understand disease management better, for more appropriate self-care and better quality of life.

3. The overall purpose of proper dietary management is to prevent early organ complications.

4. As diabetes is a lifelong disease, proper therapy methods with a special emphasis on diet should be given by healthcare providers to control the disease, reduce symptoms, and prevent complications.

5. The patients should also have good knowledge about the disease and diet. Healthcare providers must therefore recommend patients make changes in their nutritional habits and food preparation. Active and effective dietary education may prevent the onset of diabetes and its complications $[11,14,25]$. 


\section{Conclusions}

Dimensions of systematic assessment in the educational process have been shown to be important factors influencing learning. Diabetes patients can change their behavior. Research data indicate that a solid knowledge base provided to patients has a significant impact on therapy outcomes. Methodological drawbacks of our work were the unrepresentative nature of the set and the study design. The selection of respondents to the sample was intentional; the study was a cross-sectional study. Random sampling, more respondents, and the design of a prospective intervention study would address the shortcomings of this selection and design study from the generalization aspect. The results of our study may be the starting point for implementing longitudinal studies assessing the change in self-management activities based on educational programs. Based on the results of DM activities at the level of the whole sample of respondents, it is clear that there is a need for more complex continuing education in outpatient care aimed at identifying and managing patient risk behavior.

\section{References:}

1. Brunisholz KD, Briot P, Hamilton S, Joy E, Lomax M, Barton N, et al. Diabetes self-management education improves quality of care and clinical outcomes determined by a diabetes bundle measure. J Multidiscip Healthc. 2014; 7: 533-542. https://doi.org/10.2147/jmdh.s69000

2. Weaver RG, Hemmelgarn BR, Rabi DM, Sargious PM, Edwards AL, Manns BJ, et al. Association between participation in a brief diabetes education programme and glycaemic control in adults with newly diagnosed diabetes. Diabet Med. 2014; 31(12): 1610-1614. https://doi.org/10.1111/dme.12513

3. Steinsbekk A, Rygg LO, Lisulo M, Rise MB, Fretheim A. Group based diabetes self-management education compared to routine treatment for people with type 2 diabetes mellitus. A systematic review with metaanalysis. BMC Health Serv Res. 2012; 12: 213. https://doi.org/10.1186/1472-6963-12-213

4. Powers MA, Bardsley J, Cypress M, Duker P, Funnell MM, Hess Fischl A, et al. Diabetes self-management education and support in type 2 diabetes: a joint position statement of the American Diabetes Association, the American Association of Diabetes Educators, and the Academy of Nutrition and Dietetics. Clin Diabetes. 2016; 34(2): 70-80. https://doi.org/10.2337/diaclin.34.2.70

5. Majerníková L', Obročníková A, Jakabovičová A. [Education of a patient with diabetes mellitus]. MOLISA. 2007; 4: 113-115 (in Slovak).

6. Anderson RM, Pibernik-Okanovic M. The patient empowerment approach to diabetes care. Diabetologia Croatica. 1999; 4: 28-33.

7. Fitzgerald JT, Anderson RM, Gruppen LD, Davis WK, Aman LC, Jacober SJ, et al. The reliability of the diabetes care profile for African Americans. Eval Health Prof. 1998; 21(1): 52-65. https://doi.org/10.1177/016327879802100103

8. Národné centrum zdravotníckych informácií. [Activity of diabetes outpatient clinics 2016. Edition health care statistics]. Bratislava: Národné centrum zdravotníckych informácií; 2018. p. 37 (in Slovak).

9. Calhoun D, Brod R, Kirlin K, Howard BV, Schuldberg D, Fiore C. Effectiveness of motivational interviewing for improving self-care among Northern Plains Indians with type 2 diabetes. Diabetes Spectrum. 2010; 23(2): 107-114. https://doi.org/10.2337/diaspect.23.2.107

10. Murata GH, Shah JH, Adam KD, Wendel CS, Bokhari SU, Solvas PA, et al. Factors affecting diabetes knowledge in type 2 diabetic veterans. Diabetologia. 2003; 46(8): 1170-1178. https://doi.org/10.1007/s00125-003-1161-1

11. Vymětalová R, Zeleníková Z. Painful ulceration and quality of life of patients with the diabetic foot syndrome. Cent Eur J Nurs Midw. 2016; 4: 512-517.

12. Hlinková E, Nemcová J, Žiaková K. Educational assesment of diabetics requiring vascular surgery. Cent Eur J Nurs Midw. 2017; 8(4): 708-716. https://doi.org/10.15452/cejnm.2017.08.0023

13. Leino-Kilpi H, Johansson K, Heikkinen K, Kaljonen A, Virtanen H, Salanterä S. Patient education and healthrelated quality of life: surgical hospital patients as case in point. Journal of Nursing Care Quality. 2015; 20(4): 307-316. https://doi.org/10.1097/00001786-200510000-00005

14. Majerníková L'. [The impact of education professionals through the knowledge level 2 diabetic type]. Cent Eur J Nurs Midw. 2011; 2(1): 171-178 (in Slovak).

15. Mensing C, Boucher J, Cypress M. National standards for diabetes self-management education. Diabetes Care. 2000; 23(5): 682-689. https://doi.org/10.2337/diacare.23.5.682

16. Tang TS, Funnell MM, Anderson RM. Group education strategies for diabetes self-management. Diabetes Spectrum. 2006; 19(2): 99-105. https://doi.org/10.2337/diaspect.19.2.99

17. Fook L, Morgan R, Sharma P, Adekoke A, Turnbull CJ. The impact of hearing on communication. Postgraduate Medicine Journal. 2000; 76: 92-95. 
18. Chen SM, Creedy D, Lin HS, Wollin J. Effects of motivational interviewing intervention on self-management, psychological and glycemic outcomes in type 2 diabetes: a randomized controlled trial. International Journal of Nursing Studies. 2012; 49(6): 637-644. https://doi.org/10.1016/j.ijnurstu.2011.11.011

19. Ong LM, de Haes JC, Hoos AM, Lammes FB. Doctor - patient communication: a review of the literature. Social Science \& Medicine. 1995; 40(7): 903-18. https://doi.org/10.1016/0277-9536(94)00155-m

20. Sherman SE, Putnam SM, Lipkin M, Lazare A, Stoeckle J, Kekker V, et al. Annotated bibliography of doctor patient communication. West Haven, CT: Miles Institute For Health Communication, Inc; 1992.

21. Fitzgerald JT, Gruppen LD, Anderson RM, Funnell MM, Jacober SJ, Grunberger G, et al. The influence of treatment modality and ethnicity on attitudes in type 2 diabetes. Diabetes Care. 2000, 23(3): 313-318. https://doi.org/10.2337/diacare.23.3.313

22. Gurková E, Čáp J, Žiaková K. Quality of life and treatment satisfaction in the context of diabetes selfmanagement education. International Journal of Nursing Practice. 2009; 15(2): 91-98. https://doi.org/10.1111/j.1440-172x.2009.01733.x

23. Loveman E, Cave C, Green C, Royle P, Dunn N, Waugh N. The clinical and cost-effectiveness of patient education models for diabetes: a systematic review and economic evalution. Health Technology Assessment. 2003; 7(22): 1-190. https://doi.org/10.3310/hta7220

24. Štrajtenberg-Trbović V, Turk-Štrajtenberger V, Šekerija M. Standardized educational program in persons with type 2 diabetes on oral glycemic therapy: effects on glycemic control and body mass index. Diabetologia Croatica. 2011; 2: 35-40.

25. Sami W, Ansari T, Butt NS, Ab Hamid MR. Effect of diet on type 2 diabetes mellitus: a review. Int J Health Sci. 2017; 11(2): 65. 